\title{
Efek Ekstrak Kulit Mangga Arumanis terhadap Penurunan Edema Kaki Mencit Putih Jantan yang Diinduksi Karagenin
}

\section{(The Effect of Arumanis Mango Peel Extract on Decreasing the Paw Oedema in White Male Mice Induced by Carrageenin)}

\author{
Ongky Dyah Anggraini, Cicih Komariah, Aris Prasetyo \\ Program Studi Pendidikan Dokter, Fakultas Kedokteran, Universitas Jember \\ JIn. Kalimantan 37 Kampus Tegalboto, Jember 68121 \\ e-mail: cicih.fk@unej.ac.id
}

\begin{abstract}
Mango is a plant contains many active compounds with health benefits. Total phenolic content of mango peel is higher than mango flesh, with its major component are mangiferin and quercetin. Quercetin has anti-inflammatory effects through the inhibition of inflammatory mediators are serotonin, bradykinin, histamine and prostaglandin, possibly could reduce oedema as a sign of inflammation. This study used carrageenin to induce inflammation by making paw oedema in mice. The aim of this research was to know the effect of arumanis mango peel extract to reduce paw oedema in white male mice. The was quasi experimental study with 7 study groups. Spearman analyses showed a correlation with significance of $(p=$ $0.003)$ that mean it has a significant correlation $(p<0.01)$ at the $330^{\text {th }}$ min. Spearman correlation coefficients was 0,632, indicated that the dose of extract and paw oedema have strong correlation. It can be concluded that mango peel extract has effect for reducing paw oedema in white male mice, with the smallest dose was $1,002 \mathrm{mg} / \mathrm{gBW}$.
\end{abstract}

Keywords: mango, quercetin, paw oedema

\begin{abstract}
Abstrak
Mangga merupakan salah satu tumbuhan yang memiliki banyak kandungan zat aktif yang bermanfaat bagi kesehatan tubuh. Kulit mangga mengandung total fenol yang lebih tinggi daripada buahnya dengan komponen utama yaitu mangiferin dan kuersetin. Kuersetin memiliki efek sebagai anti inflamasi melalui penghambatan mediator-mediator inflamasi yaitu serotonin, bradikinin, histamin dan prostaglandin sehingga diduga dapat menurunkan edema yang merupakan tanda inflamasi. Penelitian ini menggunakan karagenin sebagai penginduksi inflamasi dengan membuat edema kaki pada mencit. Penelitian ini bertujuan untuk menunjukkan adanya efek pada pemberian ekstrak kulit mangga arumanis dalam menurunkan edema kaki mencit putih jantan. Jenis penelitian ini adalah quasi experimental dengan 7 kelompok perlakuan. Hasil uji korelasi Spearman menunjukkan adanya korelasi dengan nilai signifikansi $(p=0,003)$ yang berarti memiliki korelasi bermakna $(p<0,01)$ yaitu pada menit ke330. Koefisien korelasi Spearman sebesar 0,632 menunjukkan bahwa dosis ekstrak dan edema kaki memiliki kekuatan korelasi yang kuat sehingga dapat disimpulkan bahwa ekstrak kulit mangga arumanis dapat menurunkan edema kaki mencit putih jantan dengan dosis terkecil sebesar $1,002 \mathrm{mg} / \mathrm{gBB}$.
\end{abstract}

Keywords: mangga, kuersetin, edema kaki 
Anggraini, et al, Efek Ekstrak Kulit Mangga Arumanis terhadap Penurunan Edema Kaki...

\section{Pendahuluan}

Mangga adalah salah satu buah yang banyak digemari oleh masyarakat Indonesia , didalam mangga tersimpan kandungan zat aktif yang bermanfaat bagi kesehatan [1]. Manfaat mangga bagi kesehatan yaitu sebagai anti inflamasi, analgesik, antimikroba, antioksidan, dan anti kanker. Secara umum kulit mangga mengandung senyawa aktif seperti mangiferin, flavonoid, asam phenol, karatenoid dietary fiber, dan beberapa enzim aktif lainnya [2]. Total polifenol dalam kulit mangga yang paling utama adalah mangiferin dan kuersetin. Secara umum, kulit mangga yang mentah memiliki total polifenol yang lebih tinggi dibandingkan yang masih matang [3]. Salah satu varietas mangga terbanyak di Indonesia adalah mangga arumanis.

Kuersetin adalah salah satu senyawa flavonoid yang memiliki efek sebagai anti inflamasi. Kuersetin memiliki kemampuan untuk berikatan dengan active site COX-2 sehingga transkripsi COX-2 terganggu dan mengganggu proses ekspresi COX-2 melalui penghambatan pengikatan NF-kB dan pemblokiran koaktivator p300 [4]. Selain itu, kuersetin dapat mencegah produksi inducible nitric oxide syntase (inos) sehingga pembentukan nitric oxide yang merupakan vasodilator kuat akan terganggu [5].

Inflamasi merupakan respon protektif setempat yang ditimbulkan oleh terjadinya kerusakan jaringan [6]. Reaksi inflamasi ditandai dengan kalor (panas), dolor (nyeri), rubor (merah), penurunan fungsi, dan tumor (bengkak). Bengkak (edema) terjadi disebabkan oleh terjadinya peningkatan permeabilitas kapiler [7]. Reaksi edema dipicu oleh induksi karagenin karena injeksi karagenin tidak meninggalkan bekas, tidak menimbulkan kerusakan jaringan, dan lebih peka terhadap obat anti inflamasi dibandingkan senyawa iritan lainnya.

Terapi inflamasi dapat menggunakan obat golongan steroid dan golongan Non Steroid Anti inflammatory Drugs (NSAID). Selama ini golongan NSAID telah digunakan sebagai terapi anti inflamasi, analgesik, dan anti piretik tetapi, berdasarkan data-data yang dilaporkan sebelumnya bahwa penggunaan NSAID memiliki efek samping seperti iritasi lambung, ulkus gaster, dan induksi tukak [8].

Kulit mangga yang selama ini belum dimanfaatkan berpotensi memiliki efek anti inflamasi sehingga dilakukan penelitian mengenai hal tersebut. Dari hasil penelitian ini diharapkan dapat memberikan data dan informasi tentang efek ekstrak kulit mangga arumanis terhadap penurunan edema kaki mencit putih jantan yang diinduksi karagenin.

\section{Metode Penelitian}

Mangga yang digunakan pada penelitian ini adalah buah mangga (Mangifera indica L.) varietas arumanis yang telah diidentifikasi di Laboratorium Botani Jurusan Biologi FMIPA Universitas Jember. Kulit mangga dipilih dari buah mangga mentah yang berasal dari Ambulu, Kabupaten Jember.

Buah mangga yang telah disiapkan dikupas dan dipisahkan antara kulit buah dengan daging buah mangga. Sampel kulit buah mangga dikeringkan, kemudian dihaluskan, dan dimaserasi menggunakan etanol $80 \%$. Ekstrak cair kemudian dievaporasi menggunakan vacuum rotary evaporator untuk mendapatkan ekstrak kulit mangga kental.

Sampel pada penelitian ini adalah mencit (Mus musculus) putih jantan sebanyak 28 ekor mencit yang dibagi ke dalam tujuh kelompok perlakuan. Cara sampling menggunakan metode proportional sampling dengan Control Time Series Design sebagai desain penelitian ini. Penelitian ini telah mendapatkan persetujuan etik dari Komisi Etik Penelitian Fakultas Kedokteran Universitas Jember.

Hewan coba dibagi kedalam tujuh kelompok dengan lima kelompok perlakuan yang diberikan ekstrak kulit mangga, satu kelompok diberikan natrium diklofenak 0,0065 $\mathrm{mg} / \mathrm{gBB}$ mencit sebagai kontrol positif, dan satu kelompok diberikan $\mathrm{Na}$ CMC $1 \% 0,5 \mathrm{ml}$ sebagai kontrol negatif. Dosis kulit mangga yang diberikan adalah $0,52 \mathrm{mg} / \mathrm{grBB}$ mencit, 1,3 $\mathrm{mg} / \mathrm{grBB}$ mencit, $2,6 \mathrm{mg} / \mathrm{grBB}$ mencit, 5,2 $\mathrm{mg} / \mathrm{grBB}$ mencit, dan $26 \mathrm{mg} / \mathrm{grBB}$ mencit. Volume kaki mencit diukur menggunakan pletismometer sebelum diberikan perlakuan dan tiga puluh menit setelah diberikan ekstrak kulit mangga. Kaki mencit diberi tanda dengan menggunakan spidol pada mata kaki sebelum dimasukkan ke alat pengukur edema (pletismometer) agar pengukuran setiap pemasukan ke pletismometer selalu sama. Karagenin $1 \%$ diinjeksikan sebanyak $0,1 \mathrm{ml}$ secara subplantar kaki kiri mencit. Karagenin diinjeksikan secara subplantar pada hewan coba.

Pengukuran edema kaki dimulai 30 menit setelah injeksi karagenin. Pengukuran dilakukan setiap tiga puluh menit selama enam jam dan dicatat dalam data yang berbeda. 
Edema kaki dipresentasikan menggunakan rumus persentase radang, karena edema kaki yang diinduksi karagenin adalah model percobaan inflamasi akut. Rumus persentase radang berdasarkan metode Winter.

$\%$ radang $=(\mathrm{Vt}-\mathrm{Vo}) / \mathrm{Vo} \times 100 \%$

Penelitian ini menggunakan uji analisis statistik Korelasi Spearman dan Uji Regresi Logaritmik.

\section{Hasil Penelitian}

Hasil penelitian mengenai efek ekstrak kulit mangga terhadap penurunan edema kaki mencit yang dilihat dari rata-rata persentase radang mencit putih dapat dilihat pada tabel 1 .

Berdasarkan penelitian bahwa pada menit ke-30 seluruh kelompok perlakuan terjadi peningkatan edema jika dibandingkan dengan volume kaki sebelum diinjeksi karagenin. Pada menit ke-60 seluruh kelompok mengalami penurunan persentase radang termasuk kelompok kontrol negatif. Rata-rata persentase radang kontrol negatif terus mengalami peningkatan pada setiap waktu pengukuran, hal ini karena pada kontrol negatif tidak diberikan ekstrak atau obat.

Untuk melihat adanya efek ekstrak kulit mangga terhadap penurunan edema kaki mencit putih jantan yang diinduksi karagenin dilakukan uji analisis data.

Tabel 1. Rata-Rata Persentase Radang pada setiap kelompok sesuai waktu

\begin{tabular}{cccccccc}
\hline \multirow{2}{*}{$\begin{array}{c}\text { Waktu } \\
\text { (menit) }\end{array}$} & \multicolumn{7}{c}{ Kelompok } \\
\cline { 2 - 8 } & $\mathrm{K}+$ & $\mathrm{K}-$ & $\mathrm{P} 1$ & $\mathrm{P} 2$ & $\mathrm{P} 3$ & $\mathrm{P} 4$ & $\mathrm{P} 5$ \\
\hline 30 & 111,607 & 136,667 & 165,883 & 99,554 & 128,968 & 224,167 & 150,000 \\
60 & 98,214 & 44,167 & 104,167 & 61,607 & 23,710 & 160,000 & 68,750 \\
90 & 34,821 & 69,167 & 113,333 & 102,827 & 43,254 & 87,083 & 104,167 \\
120 & 74,107 & 69,167 & 120,000 & 65,625 & 94,048 & 209,583 & 160,417 \\
150 & 138,393 & 88,333 & 164,167 & 158,482 & 106,647 & 247,917 & 185,417 \\
180 & 211,607 & 100,833 & 197,500 & 209,970 & 80,060 & 287,917 & 260,417 \\
210 & 121,429 & 109,167 & 184,167 & 108,829 & 85,813 & 255,417 & 202,083 \\
240 & 145,536 & 143,333 & 90,833 & 113,393 & 127,282 & 155,000 & 179,167 \\
270 & 69,643 & 94,167 & 136,667 & 49,702 & 32,044 & 127,917 & 145,833 \\
300 & 190,179 & 139,167 & 191,667 & 127,232 & 121,925 & 255,000 & 287,500 \\
330 & 323,214 & 140,000 & 116,667 & 150,744 & 129,861 & 260,417 & 295,833 \\
360 & 359,821 & 186,667 & 229,167 & 154,315 & 153,968 & 300,417 & 350,000 \\
\hline
\end{tabular}

Hasil uji korelasi Spearman menunjukkan signifikansi $(p) 0,003(p<0,01)$ pada menit ke-330, hal ini mengindikasikan bahwa terdapat korelasi bermakna antara ekstrak kulit mangga arumanis dengan edema kaki. Koefisien korelasi Spearman sebesar 0,632 menunjukkan koreasi positif dengan kekuatan korelasi yang kuat. Berdasarkan analisis regresi logaritmik diketahui dosis ekstrak kulit mangga arumanis dapat menurunkan edema kaki mencit sebesar 1,002 mg/g BB.

\section{Pembahasan}

Hasil penelitian menunjukkan terdapat korelasi yang bermakna antara variabel bebas dan variabel terikat. Hal ini menunjukkan adanya efek pemberian ekstrak kulit mangga terhadap penurunan edema kaki mencit apabila dibandingkan dengan kelompok kontrol negatif. Karagenin ini berperan dalam pembentukan edema dalam model inflamasi akut [9]. 
Tanda kardinal dari inflamasi yang terjadi akibat injeksi karagenin secara subkutan adalah edema, hiperalgesia, dan eritema [10]. Edema dihasilkan dari aksi mediator inflamasi seperti histamin, serotonin, bradikinin, dan prostaglandin pada inflamasi lokal [11].

Efektivitas ekstrak kulit mangga dalam mengurangi edema dilihat dari penurunan ratarata persentase radang. Mekanisme kuersetin sebagai penurun edema atau sebagai anti inflamasi melalui 4 mekanisme, pertama kuersetin dapat berikatan dengan active site pada enzim COX-2 sehingga dapat mengganggu proses transkripsi [4]. Meknisme selanjutnya kuersetin dapat menggganggu ekspresi COX-2 melalui penghambat pengikatan transaktivator NF-kB dan pemblokiran pemasukan koaktivator p300 yang berfungsi sebagai promotor COX-2. Prostaglandin disintesis oleh enzim COX-2 sehingga apabila terjadi gangguan proses transkripsi dan ekspresi dari COX-2 maka produksinya pun akan berkurang [12]. Ketiga, kuersetin dapat mencegah produksi inducible nitric oxide syntase (iNOS), ketika terjadi inflamasi produk bakteri dan sitokin proinflamator akan menginduksi inducible nitric oxide syntase (iNOS) yang bisa memproduksi NO (Nitric Oxide) dalam jumlah besar. Nitric oxide memiliki efek vasodilator, sehingga ketika proses tersebut dihambat oleh kuersetin maka edema akan berkurang [5]. Mekanisme terakhir yaitu dengan menghambat enzim histidin dekarboksilase sehingga sintesis histamin terhambat. Ketika histamin terhambat maka efeknya terhadap vasodilatasi pembuluh darah yang menyebabkan peningkatan aliran darah dan terjadinya peningkatan permeabilitas kapiler pada awal inflamasi akan terganggu [7]. Adanya kemampuan kuersetin dalam menghambat sintesis mediator-mediator inflamasi inilah yang berperan dalam menurunkan edema pada inflamasi akut. Pada penelitian ini dosis minimal yang memiliki efek menurunkan edema kaki adalah dosis $1,002 \mathrm{mg} / \mathrm{gBB}$.

Pada menit ke-330 menunjukkan bahwa semakin tinggi dosis ekstrak yang digunakan semakin besar persentase radang yang terbentuk, hal ini diduga merupakan suatu variasi mekanisme respon tubuh (variasi biologi) karena respon setiap individu terhadap suatu obat bisa sangat bervariasi. Suatu individu dapat memberikan respon yang berlainan terhadap obat yang sama selama masa pemakaian obat. Respon tersebut dapat disebabkan oleh perbedaan genetik dalam metabolisme obat atau mekanisme imunologi [13]. Menurut Kurniawati hal tersebut disebabkan memang terdapat beberapa jenis obat dalam dosis tinggi justru menyebabkan pelepasan histamine secara langsung dari mast cell sehingga mengakibatkan pembuluh darah menjadi lebih permeabel terhadap cairan plasma dan menimbulkan proses peradangan, maka dimungkinkan pada ekstrak kulit mangga arumanis ini mengandung senyawa yang mampu mengakibatkan hal tersebut. Kemungkin lain dapat disebabkan karena adanya hewan coba yang sulit ditenangkan sehingga pada saat pengukuran, pemasukan kaki mencit pada air tidak tepat pada maleolus lateralnya [14]. Hasil penelitian dipengaruhi oleh cara penyuntikan yang merupakan trauma sehingga menyebabkan respon inflamasi terganggu, cara pengukuran volume edema yang kurang tepat serta kemungkinan adanya stress pada hewan coba [15]. Ketika stress hormon kortisol akan meningkat, efek dari peningkatan hormon tersebut dapat menghambat proses inflamasi jika efek inflamasi belum dimulai atau sebaliknya dapat menyebabkan perubahan inflamasi yang cepat dan meningkatkan proses penyembuhan jika inflamasi sudah berjalan [16].

\section{Simpulan dan Saran}

Berdasarkan hasil penelitian dapat disimpulkan bahwa ekstrak kulit mangga memiliki efek dalam menurunkan edema kaki pada mencit putih jantan yang diinduksi karagenin. Efek anti inflamasi oleh ekstrak kulit mangga bekerja dengan menghambat produksi mediator - mediator inflamasi seperti, histamin, bradikinin, serotonin dan prostaglandin.

Perlu dilakukan penelitian menggunakan metode lain untuk menguji kemampuan efek ekstrak kulit mangga sebagai anti inflamasi seperti menggunakan metode induksi histamin, asam asetat, xylene pada daun telinga mencit, brewer's yeast, formaldehid, dextran, egg albumin, kaolin, aerosil, dan formalin.

\section{Daftar Pustaka}

[1] Shah KA, Patel MB, Parmar PK. Mangifera Indica (Mango). Pharmacognosy Review. 2010; 4(7): 42-48.

[2\} Ajila CM, Naidu KA, Bhat SG, Prasada RUJS. Bioactive compounds and antioxidant potential of mango peel extract. Food Chemistry. 2007; 105: 982-988.

[3] Masibo M, He Q. Major Mango Polyphenols and Their Potential Significance to Human Health. Comprehensive Reviews in Food Science and Food Safety. 2008; 7: 309-319. 
[4] D'mello P, Gadhwal MK, Joshi U, Shetgiri P. Modelling of COX-2 Inhibitory Activity of Flavonoids. International Journal of Pharmacy and Pharmaceutical Sciences. 2011; 3 (4): 33-40.

[5] Hamalainen $M$, Nieminen $R$, Vuorela $P$, Heinonen M, Moilanen E. Anti-Inflammatory Effects of Flavonoids Inhibit STAT-1 and NF$\mathrm{kb}$ Activations, Whereas Flavone, Isorhamnetin, Naringenin, and Pelargonidin Inhibit Only NF-kb Activation Along with Their Inhibitory Effect on Inos Expression and NO Production in Activated Macrophages. Hindawi Publishing Corporation. 2007; 1-10.

[6] Dorland WAN. Kamus Kedokteran Dorland. Edisi 29. Jakarta: EGC; 2002.

[7] Corwin, Elizabeth J. Handbook of Pathophysiology. 3rd edition. Philadelphia: Lippincort Williams and Wilkins; 2008.

[8] Tyaj, Tan H, Kirana R. Obat-obat Penting. Jakarta: PT. Elex Media Komputindo; 2002.

[9] Singh A, Maholtra S, Subban R. Antiinflammatory and Analgesic Agents from Indian Medicinal Plants. International Journal of Inegrative Biology. 2008; 3(1): 57-72.

[10] Jorge S, Parada CA, Ferreira SH, Tambeli $\mathrm{CH}$. Interferential Therapy Produces Antinociception During Application in Various
Models of Inflammatory Pain. Physical Therapy. 2006; 86(6): 800-8.

[11] Anosike CA, Obidoa O, Ezeanyika LUS, Nwuba MM. Anti inflammatory and Antiulcerogenic Activity of The Ethanol Extract of Ginger (Zingiber officinale). African Journal of Biochemistry Research. 2009; 3(12): 379-384.

[12] Xiao X, Shi D, Liu L, Wang J, Xie X, Kang T, et al. Quercetin Supresses Cyclooxygenase-2 Expression and Angiogenesis trough Inactivation of P300 Signaling. Plos One. 2011; 6(8): 1-10.

[13] Katzung, Betram G. Farmakologi Dasar dan Klinik. Edisi 8. Jakarta: EGC; 2010.

[14] Kurniawati A. Uji Aktivitas Anti Inflamasi Ekstrak Metanol Graptophyllum griff pada Tikus Putih. Majalah Kedokteran Gigi Edisi Khusus Temu IImiah Nasional IV. 11-13 Agustus 2005; 167-170.

[15] Hapsari HD, Handajani J, Tandelilin RTC. Efektivitas Ekstrak Etanol Buah Mengkudu sebagai Bahan Anti Inflamasi pada Tikus Wistar. Majalah IImiah Kedokteran Gigi. 2006; 21(2): 60-68.

[16] Guyton AC, Hall JE. Buku Ajar Fisiologi Kedokteran. Edisi 11. Jakarta: EGC; 2011. 